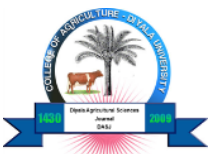

Web site: https://journal.djas.uodiyala.edu.iq/

ISSN: 2073-9524 (Print) https://dx.doi.org/10.52951/dasj.21130104

ISSN: 2310-8746 (Online)

\title{
Effect of Supplementation Selenium and Vitamin E on Blood and Stress Parameters of Awassi Lambs
}

\author{
Emad Ada-Al Dhari \\ Waleed Yousif Kassim ${ }^{1}$ \\ ${ }^{1}$ Department of Animal Production, Directorate of Agriculture, Wasit Governorate, Iraq. \\ ${ }^{2}$ Department of Animal Production, College of Agriculture, University of Basrah, Iraq. \\ ${ }^{1}$ Corresponding author gmail: waleedyosif0@gmail.com
}

\begin{abstract}
The study was established in local farm sheep in Muwafaqia / Wasit - Iraq, from 1/10/2018 until 15/1/2019, to evaluate the effect of adding selenium with or without Vitamin $\mathrm{E}$ on some of the physiological characteristics of Awassi male lambs. Sixteen lambs were selected after weaning with an average weight of (24.30) kg and aged (3-4) months. All lambs fed $2 \%$ of body weight with a concentrated diet and randomly divided into (4) groups. Control group (no additives), Selenium group ( $0.4 \mathrm{mg}$ selenium), Vitamin group (100 $\mathrm{mg}$ vitamin E) and combination of selenium + vitamin E group ( $0.4 \mathrm{mg}$ selenium $+100 \mathrm{mg}$ vitamin E) per $\mathrm{kg}$ dietary dry matter for 90 days. At the end of the experiment, blood parameters (white blood cell (WBC), red blood cell (RBC), packed cell volume (PCV), hemoglobin (HB), mean concentration hemoglobin $(\mathrm{MCH})$, and mean concentration hemoglobin count (MCHC) and stress parameters were measured. The result showed selenium + vitamin E and selenium treatments significantly increased $(\mathrm{p}<0.05)$ in PCV as compared with vitamin treatment and the control group. While treatment of vitamin significantly increased $(p<0.05)$ in hemoglobin concentration compared to treatment of combination selenium + vitamin E. Stress parameters such as respiratory rate and heartbeat decreased significantly $(p<0.05)$ in treatment of combination selenium + vitamin E compared to other treatments. There were no significant differences between the study treatments in the WBC count.
\end{abstract}

Keywords: Selenium, vitamin E, blood and stress parameters, Awassi lambs.

\section{Introduction}

The content of mineral elements provided to farm animals through diet depends on many factors, including soil characteristics, its content of mineral elements, and the period of plant growth, as deficient nutrition of mineral elements causes multiple symptoms such as poor growth, low production, and high mortality (Mazokopakis and Protopapadakis, 2007). Most environments in the world suffer from a deficiency of selenium in plants, and it is necessary to provide it in the diets of ruminants, especially in areas that suffer from an acute deficiency of this element (Flohé et al., 2000).

One of the recent studies proved that selenium has a role in reducing oxidative stress resulting from low glutathione peroxidase enzyme concentrations in ruminants (Diaz-Sanchez

\section{Dates:}

Received: 03 March 2021

Accepted 03 April 2021

Published: 30 June 2021 
et al., 2017). Many studies have indicated that selenium affects the blood parameters in goats (Diaz-Sanchez et al., 2017), cows (Slavik et al., 2008), and sheep (Boldizarova et al., 2005).

Vitamin $\mathrm{E}$ is available in wide ranges in the feed, especially as $\alpha$-tocopherol, which is the most diffusion and activation, the amounts of the vitamin $E$ increase when feeding on a green diet, as it is considered one of the antioxidants (Suttle, 2016). Vitamin E is important for animal growth and improving the health and immune status throughout improving the blood picture (Daramola et al., 2016).

Body temperature, respiratory and heartbeat rates are the most important indicators of stress that the animal is exposed under acute environmental conditions, and the combined effect of selenium and vitamin E keeps respiratory rates within the normal range during heat stress in female Bengali goats (Sivakumar, et al., (2010) and Malpura breed ewes (Sejian, et al., 2014). However, Ghanem, et al., (2016) indicated that added selenium and vitamin E in the diet of lamb, which suffers from a deficiency of the two compounds, leads to an increase in the heart rate and respiratory rates. Also, Qureshi, et al., (2017) reported that feeding ewes of the selenium $(0.3 \mathrm{mg} / \mathrm{kg}$ diet $)$ and vitamin E $(50 \mathrm{mg} / \mathrm{kg}$ diet $)$ caused a significant decrease in respiratory and heartbeat rates at the end of the experiment compared to the control group. This study aims to investigate the effect of selenium and vitamin E supplementation on the blood and stress parameters of Awassi lambs after weaning.

\section{Materials and methods}

\section{Ethical approval}

Experimental animal: all applicable national and international guidelines for the care and use of animals were followed.

\section{Experimental animal}

The experiment was conducted in local farm sheep in Muwafaqia / Wasit - Iraq, from $1 / 10 / 2018$ until $15 / 1 / 2019$ (the study period is 90 days with a 15-day preliminary period). Sixteen Awassi male lambs aged 3-4 months and weighted 24.375 $\pm 1.300 \mathrm{~kg}$ were randomly selected and divided into 4groups (4 lambs per group). The first group (control) without any additives. Second group, (Se) $0.4 \mathrm{mg}$ selenium $/ \mathrm{kg}$ of diet (produced by MERCK Company /Germany). Third group, (Vit. E) $100 \mathrm{mg}$ vitamin E/ $\mathrm{kg}$ diet (produced by HIMEDIA Company /India) and Fourth group, (Se + Vit. E) 0.4 of selenium +100 of vitamin E mg/ kg of diet, respectively. Lambs were housed in pens (one pen per group) and supplied with plastic receptacles for water and food. All animals fed daily at 7 a.m. on the same concentrate diet including barley (50\%), wheat bran (35\%), soybean meal $(5 \%)$, yellow corn $(9 \%)$, and mineral mixture without selenium $(1 \%)$, to provide the nutritional requirements of sheep according (NRC., 1985), the concentrate ration was adjusted based on $2 \%$ of the achieved weight body weekly. The remaining feed from the last day was collected and weighed for each group before the morning meal. Average total weight gain and feed conversion efficiency were calculated according to the following equations:

Average total weight gain $(\mathrm{kg})=$ final body weight - initial body weight . 
Feed Conversion Efficiency $(\mathrm{FCE})=$ weight gain $(\mathrm{kg}) \times 100 /$ feed intake $(\mathrm{kg})$

\section{Collection of blood samples and laboratory analysis}

Blood samples were taken from the jugular vein, (2) ml, placed in plastic test tubes include EDTA (Ethylene Diamine Tetra acetic acid) to determine blood pictures. White blood cells (WBC) and red blood cells (RBC) were measured by using the method of Hughes-Jones et al., (2004). Packed cell volume (PCV), hemoglobin ( $\mathrm{Hb}$ ), mean concentration hemoglobin $(\mathrm{MCH})$, and mean concentration hemoglobin count (MCHC) were measured by using the method of Dacie et al., (1984).

\section{Calculate stress measures}

The heartbeat, pulse/minute was measured using a medical headset, and breathing rate by holding the hand moistened with water in the mouth and nose of the lamb (inhalation and exhalation) / min per lamb/weekly at (7) a.m. and (6) p.m. (Alhidary et al., 2012).

\section{Statistical analysis}

The data were statistically analyzed using the Completely Randomized Design (CRD). Statistically significant differences were determined at $\mathrm{P}<0.05$. The obtained data were analyzed statistically using the SPSS, (2013).

The model was as follows:

$\mathrm{Yij}=\mu+$ Ti. + eij.

Where:

Yij : The observation of the treatment with selenium or vitamin E.

$\mu$ : The general average of the studied trait.

Ti..: The effect of the treatment.

eij.: The random error is normally distributed with a mean of zero and a variance of its magnitude $\sigma^{2} \mathrm{e}$.

\section{Results and Discussion}

\section{Average weight and feed conversion efficiency}

Treatment of combination selenium + vitamin $\mathrm{E}$ and the treatment of selenium significantly increased $(\mathrm{p}<0.05)$ for average total weight $(17.25$ and 17.60$) \mathrm{kg}$, respectively compared to treatment of vitamin and control group (12.60 and 14.60) kg, respectively, feed conversion efficiency improved in lambs of combination selenium + vitamin E treatment and selenium treatment of (4.298 and 4.349$) \mathrm{kg} / \mathrm{kg}$, respectively, compared to vitamin treatment and control group (5.647 and 4.956) kg/kg respectively. (Table 1). This increase in body weight may be due to lambs eating higher levels of dry matter and thus the higher proportion of digested energy and digested protein, which was reflected in the increase in its growth 
compared to treatments that ate less dry matter, or to the role of selenium in growth and metabolism of the bones (Cao et al., 2012), or the role of selenium and vitamin E to increase the appetite and efficiency of animal feed consumption (Shetawi et al.,1992). This is consistent with (Dominguez-Vara et al., 2009; Das, 2011; Ramadan et al., 2018) in goat and sheep.

Table 1. The effect of adding selenium and vitamin $E$ on average total weight and efficiency food conversion for lamb males (mean \pm standard error)

\begin{tabular}{|c|c|c|c|c|c|}
\hline TRT & $\begin{array}{c}\text { Initial } \\
\text { weight } \\
(\mathrm{Kg})\end{array}$ & $\begin{array}{c}\text { Final } \\
\text { weight } \\
(\mathrm{Kg})\end{array}$ & $\begin{array}{c}\text { Average } \\
\text { total weight } \\
\text { gain }(\mathrm{kg})\end{array}$ & $\begin{array}{l}\text { Feed intake } \\
(\mathrm{kg})\end{array}$ & $\begin{array}{c}\text { Feed conversion } \\
\text { efficiency } \\
(\mathrm{kg} / \mathrm{kg})\end{array}$ \\
\hline Control & $\begin{array}{l}24.40 \pm \\
1.25\end{array}$ & $\begin{array}{l}39.00 \pm \\
0.64 \mathrm{~b}\end{array}$ & $\begin{array}{c}14.60 \pm 0.53 \\
b\end{array}$ & 0.798 & 4.956 \\
\hline $\mathrm{Se}$ & $\begin{array}{c}24.60 \pm \\
1.29\end{array}$ & $\begin{array}{c}42.20 \pm \\
1.70 \mathrm{a}\end{array}$ & $\begin{array}{c}17.60 \pm 0.53 \\
\mathrm{a}\end{array}$ & 0.848 & 4.349 \\
\hline Vit. E & $\begin{array}{c}24.00 \pm \\
1.51\end{array}$ & $\begin{array}{l}36.60 \pm \\
1.24 \mathrm{c}\end{array}$ & $\begin{array}{c}12.60 \pm 0.53 \\
\mathrm{c}\end{array}$ & 0.785 & 5.647 \\
\hline Se+ Vit. E & $\begin{array}{c}24.50 \pm \\
1.14\end{array}$ & $\begin{array}{c}41.75 \pm \\
1.37 \mathrm{a}\end{array}$ & $\begin{array}{c}17.25 \pm 0.53 \\
\mathrm{a}\end{array}$ & 0.821 & 4.298 \\
\hline
\end{tabular}

Different letter within column means significant difference $(\mathrm{P}<0.05)$.

\section{Blood parameters}

Table (2) explained the effect of adding selenium and vitamin $\mathrm{E}$ on some blood pictures. The mean total number of WBC for all treatments did not record any significant differences ( $p$ <.05) among the months of the experiment. However, the values are within the normal range (Spears et al., 1986). Probably these antioxidants (selenium and vitamin) have an active mechanism for protecting the membrane cells of WBC from oxidative damage in various animal species (Chow, 1991). This is consistent with (Shinde et al., 2009; Alhidary, et al., 2012), in their study of different types of farm animals, while the results did not agree with Kassab and Mohammed, (2017) in Sohag ewes, Morán et al., (2017) in Assaf breed and (Shi et al., 2018) in black goats. The differences between those results and our result may be due to age, the duration of addiction, the different concentrations used, and physiological status. The means of RBC for combination selenium + vitamin E treatment and selenium treatment were significantly higher $(\mathrm{p}<0.05)$ recorded $(8.828$ and 8.545$)$ cell $\mathrm{x} 10^{6} / \mathrm{L}$, respectively, compared with vitamin treatment and control group (7.282 and 7.411) cell $\mathrm{x}$ $10^{6} / \mathrm{L}$ respectively, may be due to the role of selenium in maintaining the life of red blood cells, increasing it's resistance and keeping it's within the stable saline balance (isotonic) (Radostits et al., 2007), or positive correlation between selenium concentration in the blood and the effectiveness of selenium enzymes glutathione peroxidase (GPx) and superoxide dismutase (SOD) in red blood cells which reduce hemolysis (Zachara et al., 1993). Or that the vitamin is one of the basic components of the membrane of the red blood cells and its 
deficiency cause abnormalities in the red bone marrow with abnormal long-term blood changes (Radostits et al., 2007). The results were consistent with (Boldizarova et al., 2005), in male lambs of Valaska breed and (Al-Slyvany and Al-Zubaidi, 2011) in the female lamb of Awassi breed. While, the mean of PCV in combination selenium + vitamin E treatment significantly increased $(\mathrm{p}<0.05)$ recorded $(32.20 \%)$ compared with vitamin treatment and control group (29.30 and 26.70) \% respectively, this may be the result of the protective role of vitamin against hemolysis (Capper et al., 2005). These were agreed with the results of Matar et al., (2013); Morán et al., (2017); Maraba et al., (2018).

Table 2. The effect of selenium and vitamin $E$ on some of blood picture (mean \pm standard error)

\begin{tabular}{|l|c|c|c|}
\hline \multicolumn{1}{|l|}{ Trait } & WBC $\times 10^{3} / \mathrm{L}$ & $\mathrm{RBC} \times 10^{6} / \mathrm{L}$ & PCV \% \\
\hline Control & $5.201 \pm 0.294$ & $7.411 \pm 0.176 \mathrm{~b}$ & $26.70 \pm 1.115 \mathrm{c}$ \\
\hline Se & $5.106 \pm 0.905$ & $8.545 \pm 0.847 \mathrm{a}$ & $30.60 \pm 3.209 \mathrm{ab}$ \\
\hline Vit. E & $5.499 \pm 0.337$ & $7.282 \pm 0.678 \mathrm{~b}$ & $29.30 \pm 2.338 \mathrm{~b}$ \\
\hline Se+ Vit. E & $5.003 \pm 0.198$ & $8.828 \pm 0.667 \mathrm{a}$ & $32.20 \pm 2.692 \mathrm{a}$ \\
\hline
\end{tabular}

Different letter within column means significant difference $(\mathrm{P}<0.05)$.

Vitamin treatment increased significantly $(\mathrm{p}<0.05)$ in hemoglobin concentration reached $(10.26 \mathrm{~g} / 100 \mathrm{ml})$ compared to combination selenium + vitamin E treatment which reached $(8.90 \mathrm{~g} / 100 \mathrm{ml})$. MCH increased significantly $(\mathrm{p}<0.05)$ in vitamin treatment which recorded (27,90 picogm) compared to combination selenium + vitamin E treatment, selenium treatment and control group which recorded (17.90, 21.30 and 21.00) Picogm, respectively, In addition, MCHC increased significantly $(\mathrm{p}<0.05)$ for vitamin treatment $(78.10 \mathrm{~g} / 100 \mathrm{ml})$ compared to combination selenium + vitamin E treatment, selenium treatment and control group (49.20, 58.80 and 59.10) g/100 ml, respectively (Table 3). The significant increase in the mean amount of hemoglobin in erythrocytes $(\mathrm{MCH})$ and concentration of hemoglobin in erythrocytes (MCHC) for vitamin treatment, the reason for this may be that vitamin E plays a role in maintaining the persistence of metabolism, which strengthens the need to improve standards blood, including hemoglobin, is the necessary oxygen transporter for such processes (Huisman, 1975). This is consistent with (Alhidary et al., 2012; Soliman et al., 2012). However, it does not agree with (Morán et al., 2017; Maraba et al., 2018).

Table 3. The effect of selenium and vitamin $E$ on some blood picture (mean \pm standard error)

\begin{tabular}{|c|c|c|c|}
\hline $\begin{array}{c}\text { Trait } \\
\text { TRT }\end{array}$ & $\mathrm{Hb} \mathrm{g} / 100 \mathrm{ml}$ & MCH Pico gm & MCHC g/100 ml \\
\hline Control & $9.30 \pm 0.35 \mathrm{ab}$ & $21,00 \pm 1.19 \mathrm{~b}$ & $59.10 \pm 3,31 \mathrm{~b}$ \\
\hline
\end{tabular}




\begin{tabular}{|c|c|c|c|}
\hline Se & $9.43 \pm 0.31 \mathrm{ab}$ & $21,30 \pm 2.24 \mathrm{~b}$ & $58.80 \pm 7,00 \mathrm{~b}$ \\
\hline Vit. E & $10.26 \pm 0.43 \mathrm{a}$ & $27,90 \pm 1.79 \mathrm{a}$ & $78.10 \pm 4,53 \mathrm{a}$ \\
\hline Se+ Vit. E & $8.90 \pm 0.42 \mathrm{~b}$ & $17,90 \pm 0.86 \mathrm{~b}$ & $49.20 \pm 2,83 \mathrm{~b}$ \\
\hline
\end{tabular}

Different letter within column means significant difference $(\mathrm{P}<0.05)$.

\section{Stress parameters}

A Significant $(\mathrm{p}<0.05)$ decrease was observed for respiratory rate and heartbeat in treatment of combination selenium + vitamin E, with (42) respiratory movement /minute and (88) pulse /minute respectively compared with other treatments (Table 4). It may be due to the role of vitamin + mineral supplementation by lowering cortisol in the blood (Sivakumar et al., 2010). As the release of this hormone is one of the main signs of stimulating the hypothalamic-pituitary-adrenal gland axis as a physiological reaction by these glands to face the state of stress in the body, the hormone works to regulate the respiratory rate and heartbeat during stress state (Ihsanullah et al., 2017), it is considered a general stress hormone and performs a decisive effect in many physiological activities, especially respiratory rate, heartbeat and body temperature (Marai et al., 2000), or to the direct effect of vitamin on the thermal regulation zone in the hypothalamus (Ganong, 2001). This is consistent with the results of (El-Shahat and Abdel Monem, 2011; Alhidary et al., 2012), for breathing rate, while, this result did not agree with the results indicated (Katamoto et al., 1998) in terms of respiratory rate when injected selenium and vitamin after exposing goats to heat stress. While, agreed in a heartbeat with Qureshi et al., (2017) in ewes of Damani and Balkhi breeds and with Ghanem et al., (2016) in lambs. However, it differed from the results of Chauhan et al., (2016), this variation may be attributed to the type and breed of experimental animals and stressful environmental studies.

Table 4. The effect of selenium and vitamin $E$ on stress parameters (mean \pm standard error)

\begin{tabular}{|c|c|c|}
\hline TRT & $\begin{array}{c}\text { Respiratory rate } \\
\text { Respiratory } \\
\text { movement/minute }\end{array}$ & $\begin{array}{c}\text { Heartbeat } \\
\text { Pulse/minute }\end{array}$ \\
\hline Control & $59 \pm 0.85 \mathrm{a}$ & $102 \pm 0.57 \mathrm{a}$ \\
\hline Se & $55 \pm 0.57 \mathrm{a}$ & $104 \pm 0.86 \mathrm{a}$ \\
\hline Vit. E & $53 \pm 0.85 \mathrm{a}$ & $100 \pm 2.01 \mathrm{a}$ \\
\hline Se+ Vit. E & $42 \pm 0.85 \mathrm{~b}$ & $88 \pm 0.75 \mathrm{~b}$ \\
\hline
\end{tabular}

Different letter within column means significant difference $(\mathrm{P}<0.05)$.

\section{Conclusions}

The results showed that add element selenium (0.4) $\mathrm{mg}$ with $100 \mathrm{mg}$ of vitamin $\mathrm{E} / \mathrm{Kg}$ of dry matter to the diets of lambs achieved improved significantly in most of the qualities of productivity and rates of growth as a live body weight final daily gain, proved to be effective 
in improving the standards lambs treatment as the number of cells of blood the red and the size of cells compressed and hemoglobin blood and the average quantity and the average concentration in red blood cells and indicators to overcome the conditions of stress improvement in the rate of breathing and pulse of the heart.

\section{Conflict of interest}

The authors declare that they have no conflict of interest.

\section{Acknowledgments}

We would like to thank the owner of the field for his cooperation with us in completing the study period and providing the requirements for breeding. We also We are also grateful to the manager of the physiology laboratory in our department for his help in the laboratory analyzes.

\section{References}

Alhidary, I. A., S. Shini, R. A. M. Al Jassim and J. B. Gaughan. 2012. Effect of various doses of injected selenium on performance and physiological responses of sheep to heat load1. J. Anim. Sci., 90: 2988-2994.

Al-Slyvany, A. S. and A. A. Al-Zubaidi. 2011. Effect of Vitamins A and E on Some Reproduction Parameters in the Sheep. Anbar. J. Agri. Sci., 9 (1): 162-172.

Boldizarova, K., L. Gresakova, S. Faix, M. Mellen and L. Leng. 2005. Antioxidant status of lambs fed on diets supplemented with selenite or Se-yeast. J. Anim. and Feed Sci., 14: $245-253$.

Cao, J. J., B. R. Gregoire and H. Zeng. 2012. Selenium deficiency decreases antioxidative capacity and is detrimental to bone microarchitecture in mice. J. Nutr., 142(8): 15261531 .

Capper, J. L., R. G. Wilkinson, E. Kasapidou, S. E. Pattinson, A. M. Mackenzie and L. A. Sinclair. 2005. The effect of dietary vitamin E and fatty acid supplementation of pregnant and lactating ewes on placental and mammary transfer of vitamin $\mathrm{E}$ to the lamb. Brit. J. Nutr., 93 (4): 549-557.

Chow, C. K. 1991. Vitamin E and oxidative stress. Free Radic. Biol. Med., 11(2): 215-232.

Dacie, J. V. and S. M. Lewis (ed.). 1984. Basic Haematological Techniques, Practical Haematology. Churchill livingstone. New York, USA.

Daramola, J. O., E. O. Adekunle, O. E. Oke, O. Ogundele, E. O. A. Saanu and A. J. Odeyemi. 2016. Effect of vitamin E on sperm and oxidative stress parameters of West African dwarf goat Bucks. J. Tropi. \& Subtropic. Agroec., 19 (2): 151-158. 
Das, T. K. (2011). Effect of vitamin E supplementation on stress related genes, oxidative stress immunity and milk production in arsenic exposed goat. Doctorate of philosoph y in animal nutrition, national dairy research institute, deemed university, Karnal, India.

Díaz-Sánchez, V. M., G. Rodríguez-Patiño, P. Ramírez-Noguera, J. E. Ramírez-Bribiesca, J. F. Morales-Álvarez, A. L. Revilla-Vázquez and R. López-Arellano. 2017. Dose of selenium in goat kids and its effect on the antigenic response to Mannheimia haemolytica and oxidative stress. Small Rumin. Res., 153: 171-174.

Dominguez-Vara, I. A., S. S. González-Mũnoz, J. M. Pinos-Rodríguez, J. L. BórquezGastelum, R. Bárcena-Gama, G. Mendoza-Martínez, L. E. Zapata and L. L. LandoisPalencia. 2009. Effects of feeding selenium-yeast and chromium-yeast to finishing lambs on growth, carcass characteristics, and blood hormones and metabolites. J. Anim. Feed Sci. Tech., 152 (1-2): 42-49.

El-Shahat, K.H. and U.M. Abdel Monem. 2011. Effects of dietary supplementation with vitamin $\mathrm{E}$ and /or selenium on metabolic and reproductive performance of Egyptian Baladi ewes under subtropical conditions. J. World Appl. Sci., 12 (9): 1492-1499.

Flohé, L., J. R. Andreesen, R. Brigelius F., M. Maiorino and F. Ursini. 2000. Selenium, the element of the moon, in life on earth. IUBMB life, 49 (5): 411-420.

Ganong, W. F. 2001. Hormonal Control of Calcium Metabolism and the Physiology of Bone. Text book of review of medical physiology, Boston, USA.

Ghanem, M. M., M. R. Anwar, Y. M. Abd El-Raof and H. M. El-Attar 2016. Clinical, hematological and biochemical changes in lambs suffered from nutritional muscular dystrophy. J. Benha Vet. Med., 30 (2): 61-66.

Chauhan, S.S. E.N. Ponnampalam, P. Celi, D.L. Hopkins, B.J. Leury and F.R. Dunshea. 2016. High dietary vitamin $\mathrm{E}$ and selenium improves feed intake and weight gain of finisher lambs and maintains redox homeostasis under hot conditions. Small Rumin Res., 137: $17-23$.

Huisman, T. H. (ed.). 1975. The blood of sheep: composition and function. M. H. Blunt. New York, Springer-Verlag.USA.

Ihsanullah, A., M.S. Qureshi, S.M. Suhail, S. Akhtar and R.U. Khan. 2017. Postpartum ovarian activities, blood metabolites and milk yield are influenced by changing levels of thermal stress in crossbred dairy cows. Int. J. Biomaterial., 61 (9): 1561-1569.

Kassab, A. Y., and A. A. Mohammed. 2015. Effect of Vitamin E and Selenium on Some Physiological and Reproductive Characterististics of Sohagi Ewes. J. Egyptian. Sheep and Goat. Sci., 65 (2363): 1-1. 
Katamoto, H., H. Fukuda, I. Oshima, N. Ishikawa and Y. Kanai. 1998. Nitroblue terazolium reduction of neutrophils in heat stressed goats is not influenced by selenium and vitamin E injection. J. Vet. Med. Sci., 60(11):1243-1249.

Maraba, K. P., V. Mlamboa, A. O. Yusuf, U. Marume and A. Hugo. 2018. Extra dietary vitamin $\mathrm{E}$ - selenium as a mitigation strategy against housing-induced stress in Dohne Merino lambs: Effect on growth performance, stress biomarkers, and meat quality. J. Small Rumin. Res., 160: 31-37.

Marai, I., L. Bahgat, T. Shalaby and A. Hafez. 2000. Response of male lambs to concentrate mixtures given with or without natural clay under Egypt conditions. Ann. Arid Zone, 39 (4): 449-460.

Matar, H.A., U. S. Askar and S. O. Al Mawla. 2013. Influence of selenium and zinc on some immunological properties of Iraqi ewes. Anbar Unive. J. Pure Sci, 7 (2): 55-63.

Mazokopakis, E. E. and E. E. Protopapadakis. 2007. Recommended dietary selenium intakes and selenium concentrations in nuts. J. Hellenic of Nuclear Med., 10 (1): 34-40.

Morán, L., S. Andrés, C. Blanco, J. Benavides, M. Martínez-Valladares, A. P. Moloney and F. J. Giráldez. 2017. Effect of dietary supplementation with carnosic acid or vitamin E on animal performance, haematological and immunological characteristics of artificially reared suckling lambs before and after road transport. J. Arch. Anim. Nutr., 71 (4): $272-284$.

NRC. 1985. Nutrient Requirements of Sheep. 6th rev (ed.). Natl. Acad. Press, Washington, DC., USA. Pp 112.

Qureshi, M. S., S. Akhtar and R. U. Khan. 2017. The effect of vitamin E and selenium on physiological, hormonal and antioxidant status of Damani and Balkhi sheep submitted to heat stress. Appl. Biol. Chem., 60 (6): 585-590.

Radostits, O. M., C. C Gay, K. W. Hinchcliff and P. D. Constable. (ed.). 2007. Veterinary Medicine: A Textbook of the diseases of Cattle. Horses, Sheep, Pigs and Goats. Saunders. Elsevier. Spain.

Ramadan, S. G. A., H. D. H. Mahboub, M. A. Y. Helal and M. A. Sallam. 2018. Effect of vitamin $\mathrm{E}$ and selenium on performance and productivity of goats. Int. J. Chem. Bio. Sci., 4 (2): 16-22.

Sejian, V., A. K. Singh, A. Sahoo and S. M. K. Naqvi. 2014. Effect of mineral mixture and antioxidant supplementation on growth, reproductive performance and adaptive capability of Malpura ewes subjected to heat stress. J. Anim. Physiol. Anim. Nutr., 98 (1): 72-83. 
Shetawi, M. M., H. A. Daghash and T. S. Abd El-All. 1992. Growth performance, hematology and serum profiles of coarse-wool lambs as influenced by supplemental vitamin E. Assuit Vet. Med. J., 54: 64-70.

Shi, L.; Y. Ren, C. Zhanga, W. Yuea and F. Lei. 2018. Effects of organic selenium (Seenriched yeast) supplementation in gestation diet on antioxidant status, hormone profile and haematobiochemical parameters in Taihang black goats. J. Anim. Feed Sci. Techno. 238: 57-65.

Shinde, P. L., R. S. Dass and A. K. Garg. 2009. Effect of vitamin E and selenium supplementation on haematology, blood chemistry and thyroid hormones in male buffalo (Bubalus bubalis) calves. J. Anim. Feed Sci., 18 (2): 241-256.

Sivakumar, A. V., N. G. Singh and V. P. Varshney. 2010. Antioxidants supplementation on acid base balance during heat stress in goats. Asian-Aust. J. Anim. Sci., 23 (11): $1462-1468$.

Slavik, P., J. Illek, M., Brix, J. Hlavicova, R. Rajmon and F. Jilek. 2008. Influence of organic versus inorganic dietary selenium supplementation on the concentration of selenium in colostrum, milk and blood of beef cows. J. Acta. Vet. Scandinavica., 50 (43) :1-6.

Soliman, E.B., A.K. Ibrahim and A.Y. Kassab. 2012. The combined effect of vitamin E and selenium on some of the productive and physiological characteristics of ewes and their pregnancy during lactation. J. Egyptian Sheep Goat. Sci., 7(2): 31- 42.

Spears, J. W., R. W. Harvey and E. C. Segerson. 1986. Effects of marginal selenium defi ciency and winter protein supplementation on growth, reproduction and selenium status of beef cattle. J. Anim. Sci., 63 (2): 586-594.

SPSS. 2013. Statistical package for Social Science, version 16. Users guide for statistical, Chicago. USA.

Suttle, N. F. 2016. Ruminant nutrition - digestion and absorption of minerals and vitamins. J. Elsevier Livest. Sci., 55: 125-134.

Zachara, B. A., J. Mikolajczak and U. Trafikowska. 1993. Effect of various dietary selenium (Se) intakes on tissue Se levels and glutathione peroxidase activities in lambs. J. Vet. Med., 40 (1-10): 310-318. 